\title{
Aneurysmal bone cyst of thoracic spine: case report and brief review of literature
}

\author{
Anupam Jaiswal, ${ }^{1}$ Varun Vijay, ${ }^{2}$ Prakash Kori, ${ }^{1}$ Rakesh Shukla ${ }^{1}$
}

${ }^{1}$ Department of Neurology, King George's Medical University, Lucknow, Uttar Pradesh, India ${ }^{2}$ Department of Orthopaedics, King George's Medical University, Lucknow, Uttar Pradesh, India

Correspondence to Professor Rakesh Shukla, rakeshshukla_rakesh@ rediffmail.com

\footnotetext{
To cite: Jaiswal A, Vijay V, Kori $P$, et al. BMJ Case Rep Published online: [please include Day Month Year] doi:10.1136/bcr-2013009265
}

\begin{abstract}
SUMMARY
A 16-year-old girl was admitted with insidious onset, gradually progressive spastic sensori-motor paraparesis, with a sensory level at D10 dermatome without bowel or bladder involvement for the last 2 months following trivial trauma on the lower back. MRI of the spine showed a low-to-intermediate signal intensity, heterogeneous mass with multiple fluid levels. A diagnosis of aneurysmal bone cyst was made. A D8-D9 laminectomy with near total excision of mass was performed. Histopathology of the mass showed cyst cavity filled with haemorrhage surrounded by bony trabeculae confirming the diagnosis. Following excision the patient had excellent recovery. We report this case owing to its rarity and to emphasise the importance of surgery if there is cord compression.
\end{abstract}

\section{BACKGROUND}

Aneurysmal bone cyst (ABC), comprising 1.4\% of all primary bone tumours and $15 \%$ of all primary spine tumours, is a rare benign tumour. ${ }^{1}{ }^{2}$ It is pathologically characterised by cystic, blood-filled spaces surrounded by thinned out cortical bone. ${ }^{1}$ Thoracic $(32 \%)$ and lumbar spine $(34 \%)$ involvement is common. ${ }^{1}$ Back pain is the commonest presentation. ${ }^{1}$ Rarely, cord compression with neurological deficit is seen. ${ }^{3}$ Multiple treatment modalities have been tried with variable improvement and recurrence rates. ${ }^{4-8} \mathrm{As} \mathrm{ABC}$ is a rare entity, no clear cut indication for any of the treatment modality is described. We report a case of dorsal spine $\mathrm{ABC}$, treated with complete surgical resection and excellent recovery, keeping in mind, its rarity and to emphasise the need for complete surgical resection, if cord compression is present.

\section{CASE PRESENTATION}

A 16-year-old girl was admitted with insidious onset, gradually progressive spastic sensori-motor paraparesis with a sensory level at D10 dermatome without bowel or bladder involvement for the last 2 months following minor trauma on the lower back. Examination of the spine showed a localised swelling with tenderness over D8-D9 vertebra. Other examination findings were $\mathrm{B} / \mathrm{L}$ grade 2 spasticity, power $2 / 5$ and brisk deep tendon reflexes in both lower limbs with $\mathrm{B} / \mathrm{L}$ extensor plantar response. She had decreased pin prick and temperature sensation below the D10 dermatome. Joint position and vibration sense was impaired in both lower limbs. Romberg's sign could not be tested. Rest of the examination was normal.

\section{INVESTIGATIONS}

MRI of dorsal spine (figure 1) revealed an illdefined heterogeneously enhancing mass $(5.8$ $\mathrm{cm} \times 4.0 \mathrm{~cm} \times 3.8 \mathrm{~cm}$ ) with focal areas of necrosis involving posterior elements of the spine and paraspinal soft tissue at D7-D8 level. The lesion was hypointense on both T1-weighted and T2-weighted images. It was extending into posterior epidural space at D7 level causing cord compression with myelopathic changes. CT of thoracic spine (figure 2) showed a well-defined expansile enhancing soft tissue lesion $(5.3 \mathrm{~cm} \times 3.1 \mathrm{~cm} \times 4.0 \mathrm{~cm})$ with multiple enhancing septations, involving posterior elements of D8 and D9. Non-enhancing hypodense areas were seen within the lesion suggestive of necrosis. Multiple coarse calcifications were also evident. The lesion was extending into posterior epidural space causing compression over the underlying cord. During surgical exploration of the spine at the level of D8-D9, a grey-red fleshy mass, $5 \mathrm{~cm}$ long with multiple blood-filled cysts, was removed and sent for histopathology (figure 3). The finding of cyst cavity filled with haemorrhage and surrounded by bony trabeculae on H\&E staining was consistent with the diagnosis of $\mathrm{ABC}$.

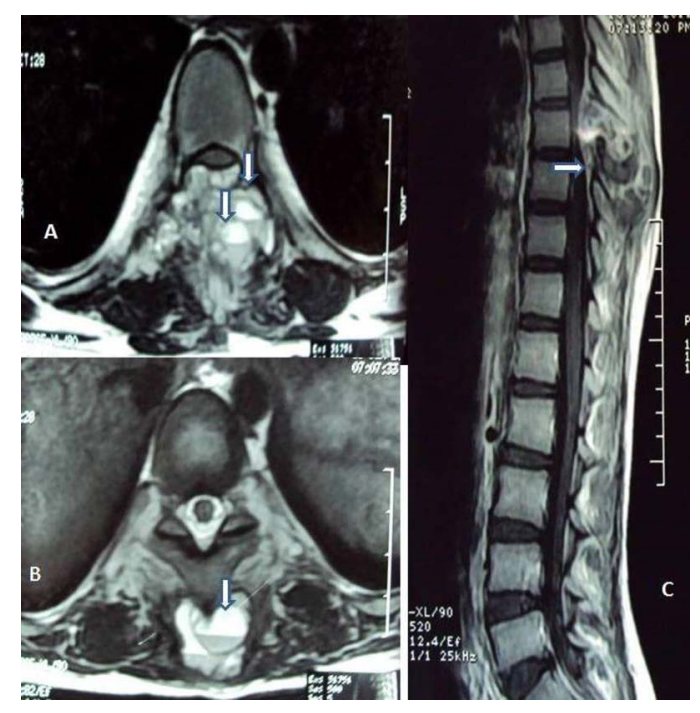

Figure $1 \mathrm{MRI}$ of the spine. (A) Axial T1-weighted - low-to-intermediate signal intensity, heterogenous mass with multiple fluid levels (arrows). (B) Axial T2-weighted-large, expansile spinal lesion with multiple fluid levels (arrows), typical for an aneurysmal bone cyst . Rim of low signal intensities with internal septa producing a multicystic appearance is also evident. (C) Sagittal T1 with (GAD)-ill-defined heterogeneously enhancing mass (arrow). 


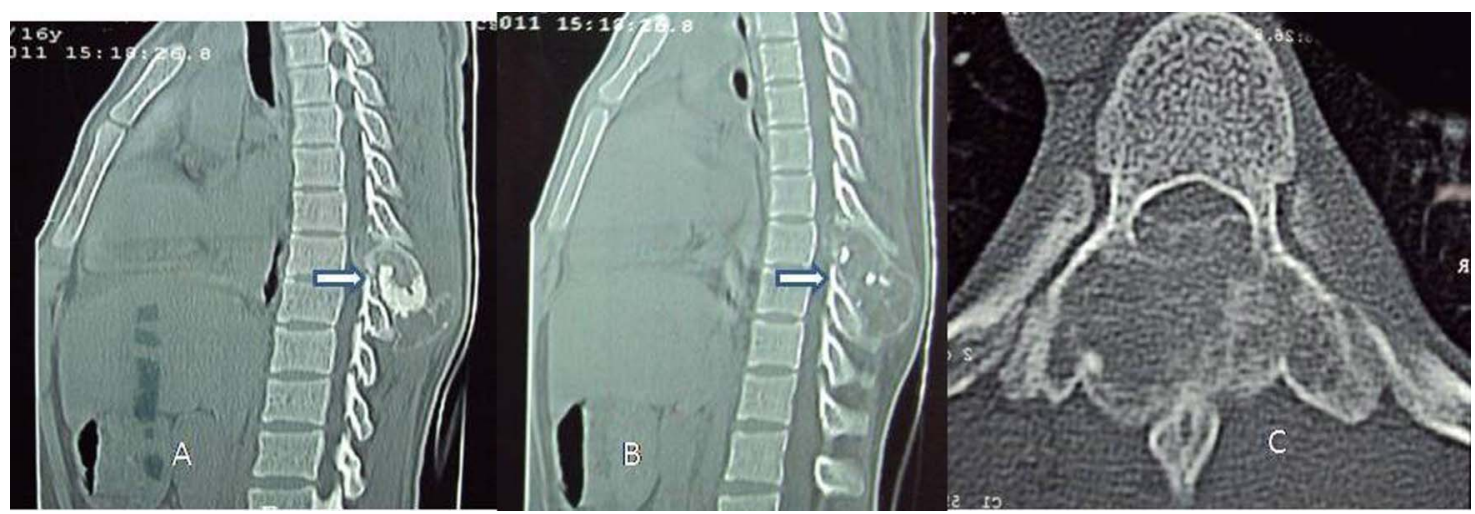

Figure 2 CT of the spine (A) Saggital section showing typical expansile, lytic lesion with a so-called egg shell layer of cortical bone surrounding the lesion (arrow). (B) Egg shell (arrow). (C) Axial section showing lytic lesion with egg shell layer involving spine and laminae with posterior epidural extension and compression over cord.

\section{DIFFERENTIAL DIAGNOSIS}

Differential diagnosis included osteoblastoma, osteoid osteoma, giant cell tumour and fibrous dysplasia. Non-neoplastic causes to be considered are osteomyelitis, juvenile rheumatoid arthritis, systemic lupus erythematous and Scheuermann disease. ${ }^{9}$

\section{TREATMENT}

D8-D9 laminectomy with near total excision of mass was performed (figure 4).

\section{OUTCOME AND FOLLOW-UP}

Postoperative hospital stay was uneventful and there was improvement in sensory symptoms at the time of discharge. At follow-up after 1 month, power in both lower limbs improved to $4 / 5$ with complete sensory recovery. After 1 year of follow-up the patient had excellent recovery without any residual deficit.

\section{DISCUSSION}

Jaffe and Lichtenstein ${ }^{10}$ described the first case of ABC in 1942. The word 'Aneurysmal' in $\mathrm{ABC}$ refers to blow-out distension owing to thinned out cortex with minimal bone formation, and 'Bone Cyst' are the blood-filled cavities in the tumour. The incidence is $0.14 / 100000$ people with slight female preponderance, and onset in the first two decades. The common sites of occurrence are femur, tibia, humerus, spine, pelvis, ribs and small bones of the hands and feet. ${ }^{11}$ In the spine, lumbar involvement $(34 \%)$ is followed by thoracic spine (32\%) and cervical spine. ${ }^{12}$ $\mathrm{ABC}$ in the spine (ABCS) usually arises from posterior osseous elements, vertebral bodies being occasionally affected and rarely alone. This may spread to another vertebrae, adjacent rib, paraspinal soft tissues but intervertebral disc is not involved. ${ }^{13}$ Scoliosis and kyphosis is found in $10-15 \%$ of patients. ${ }^{11}$

The cause is largely unknown, although many hypotheses have been proposed ${ }^{14}$ which include improper repair of a traumatic subperiosteal haemorrhage, a vascular disturbance of the bone or haemorrhage into a pre-existing lesion.

The natural history consists of four phases ${ }^{12}$

1. Osteolysis phase: eccentric rarefaction area with little or no internal structure.

2. Active growth phase: subperiosteal blow-out pattern owing to rapid destruction of bone.

3. Mature stage: soap bubble appearance, distinct peripheral bony shell and internal bony septae and trabeculae.

4. Healing phase: progressive calcification and ossification of the cyst.

Local pain is the commonest presentation. ${ }^{1}$ Injury as a preceding event, as in our case, has been reported earlier. ${ }^{15}$ Local haemodynamic alterations in the form of venous obstruction or arteriovenous fistulae occuring after an injury could be important in its pathogenesis relating to injury. ${ }^{15}$ Rapidly expanding
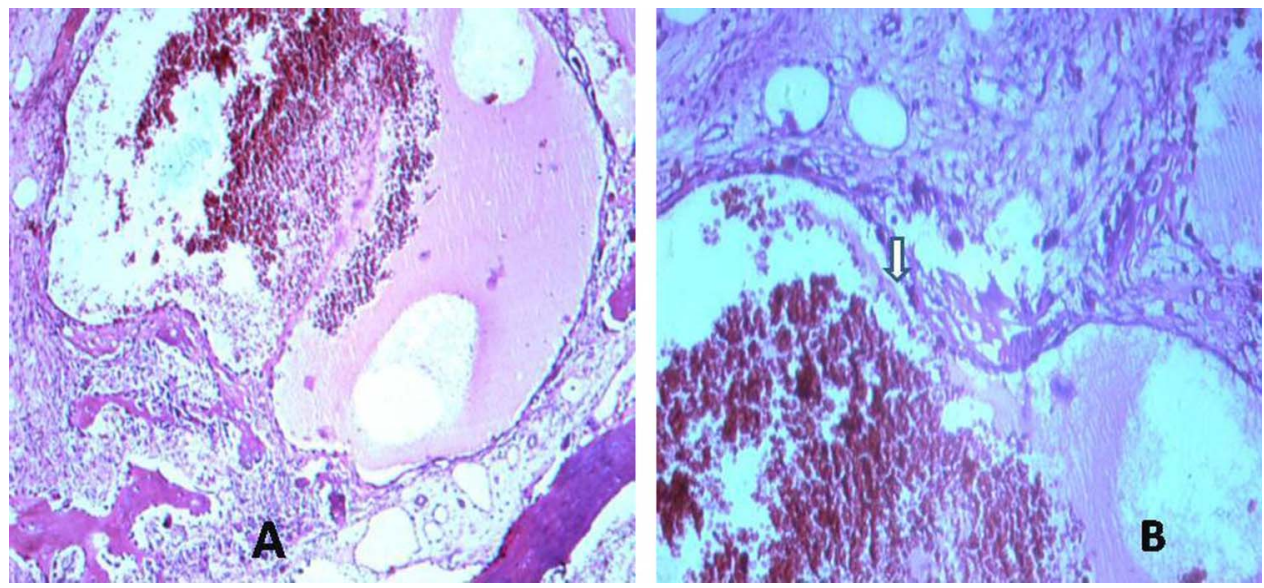

Figure 3 Histopathology. Microphotograph showing cyst cavity filled with haemorrhage and surrounded by bony trabeculae (H\&E $\times 4$ ). (A) Microphotograph showing cyst cavity filled with haemorrhage and surrounded by foreign body giant cells (shown by arrow H\&E $\times 10$ ). 


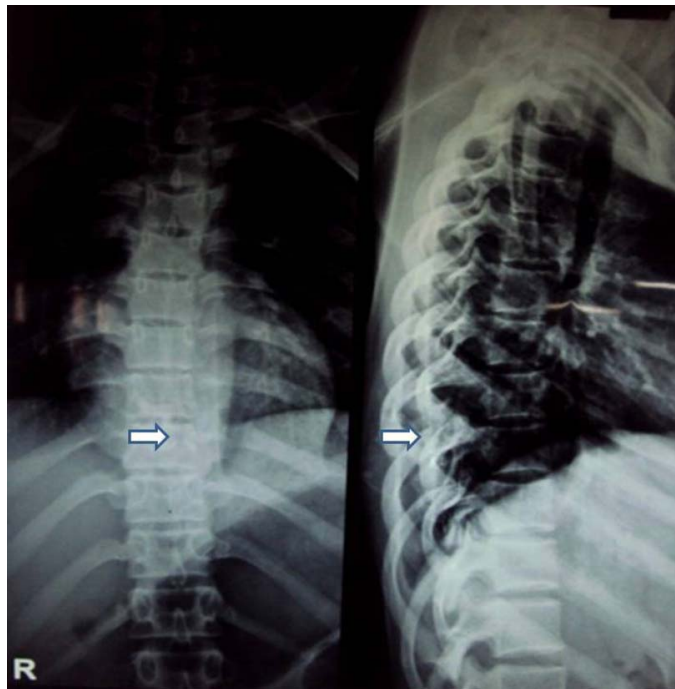

Figure 4 Postoperative X-ray of dorsal spine showing absent D8 and D9 spine (arrow).

$\mathrm{ABC}$ or vertebral body collapse can cause epidural spinal cord compression, kyphotic deformity and acute paraparesis. ${ }^{3}$ Acute spinal cord compression in the absence of vertebral body collapse can occur if there is a break in the posterior cortex of the body. The diagnosis is usually made $4-8$ months after onset of symptoms. Rapid deterioration to complete paraplegia may occur if lesions are left untreated.

MRI is more sensitive than CT. ${ }^{14}$ Fluid levels in different cystic cavities could be seen. MRI is also the best imaging modality for demonstrating multiple internal septa, epidural extension and compressive effect.

The treatment of ABCS has remained a topic of controversy, due to lack of definite guidelines. Treatment options (table 1) in

Table 1 Comparative analysis of treatment modalities

\begin{tabular}{|c|c|c|}
\hline $\begin{array}{l}\text { SI. } \\
\text { no. }\end{array}$ & Treatment modality & Comment \\
\hline 1 & $\begin{array}{l}\text { Curettage with or without bone } \\
\text { grafting }^{8}\end{array}$ & $\begin{array}{l}\text { Approximately } 19 \% \text { recurrence } \\
\text { rate, usually within the first } 2 \text { years } \\
\text { of post-treatment }\end{array}$ \\
\hline 2 & Complete excision ${ }^{112}$ & $\begin{array}{l}\text { Treatment of choice for patients } \\
\text { presenting with a neurological } \\
\text { deficit. En-bloc total excision, if } \\
\text { possible, provides the highest rate } \\
\text { of cure }\end{array}$ \\
\hline 3 & Partial excision ${ }^{12}$ & $\begin{array}{l}\text { Recurrence rate is } 25 \% \text {, usually } \\
\text { seen within } 6-12 \text { months }\end{array}$ \\
\hline 4 & Arterial embolisation ${ }^{4} 61819$ & $\begin{array}{l}\text { Could be the first choice or } \\
\text { combined with other modality }\end{array}$ \\
\hline 5 & Radiation $^{7} 16$ & $\begin{array}{l}\text { Adjuvant therapy for patients with } \\
\text { inoperable lesions, aggressive } \\
\text { recurrent disease, or medical } \\
\text { conditions that place them at high } \\
\text { risk during surgery }\end{array}$ \\
\hline 6 & $\begin{array}{l}\text { Injection of the cyst with a } \\
\text { sclerosing solution (alcoholic zein) }\end{array}$ & $\begin{array}{l}\text { Complete improvement in } 87 \% \text { of } \\
\text { cases and partial healing in } 13 \% \text {, } \\
\text { with a } 5 \% \text { incidence of serious } \\
\text { complications }\end{array}$ \\
\hline 7 & $\begin{array}{l}\text { Percutaneous intralesional injection } \\
\text { of calcitonin and } \\
\text { methylprednisolone }\end{array}$ & No recurrence reported \\
\hline
\end{tabular}

various case series or reports have included simple curettage with or without bone grafting, complete excision, embolisation, radiation therapy or a combination of these modalities. ${ }^{8} 11$

Simple curettage can result in obliteration of the cyst. ${ }^{11}$ Curettage and bone grafts have a 20\% recurrence rate. Recurrences are managed with more aggressive curettage or excision. ${ }^{8}$ Surgical stabilisation is needed if postoperative deformity develops.

Radiotherapy is the treatment modality for patients at high risk of surgery and for those who are resistant to surgical treatment or are at high risk for surgery. ${ }^{16}$ Complications of radiotherapy are sarcomatous change, myelopathy and deformation of vertebrae. ${ }^{17}$

Selective embolisation is preferred for large tumours, having high risk of bleeding and in places where curettage is technically difficult. ${ }^{18}$ Embolisation has been preferred as the first option in recent years for intact $\mathrm{ABC}$ when diagnosis is certain, when technically feasible and safe and when no pathological fracture or neurological involvement are found. ${ }^{19}$ Intralesional injection of sclerosing agents is also an effective method and cure rates of $87 \%$ have been reported. ${ }^{4}$ Percutaneous intralesional injection of calcitonin and methylprednisolone has been used as an important alternative to surgery without recurrence at the end of 2.5 years. $^{20}$

Recurrences are likely within 2 years of treatment. So a follow-up of 5 years is advocated. Radiation treatment requires life long follow-up. ${ }^{13}$

\section{Learning points}

- Aneurysmal bone cyst of spine is a rare, benign, treatable condition.

- MRI is the most sensitive investigation.

- Cord compression should be treated by complete excision.

Contributors AJ prepared the manuscript, VV assisted in literature review, PK contributed in editing and literature review and RS finalised the manuscript.

\section{Competing interests None.}

Patient consent Obtained.

Provenance and peer review Not commissioned; externally peer reviewed.

\section{REFERENCES}

1 Ameli NO, Abbassioun K, Saleh $\mathrm{H}$, et al. Aneurysmal bone cysts of the spine. Report of 17 cases. J Neurosurg 1985;63:685-90.

2 Dahlin DC, McLeod RA. Aneurysmal bone cyst and other non-neoplastic conditions. Skeletal Radiol 1982;8:243-50.

3 Raftopoulos C, Hurrel A, Ticket L, et al. Total recuperation in a case of sudden total paraplegia due to an aneurysmal bone cyst of the thoracic spine. Childs Nerv Syst 1994;10:464-7.

4 Guibaud L, Herbreteau D, Dubois J, et al. Aneurysmal bone cysts: percutaneous embolization with an alcoholic solution of zein-series of 18 cases. Radiology 1998;208:369-73.

5 Szendröi M, Antal I, Liszka G, et al. Calcitonin therapy of aneurysmal bone cysts. J Cancer Res Clin Oncol 1992;119:61-5.

6 Koci TM, Mehringer CM, Yamagata N, et al. Aneurysmal bone cyst of the thoracic spine: evolution after particulate embolization. AJNR Am J Neuroradiol 1995; 16:857-60.

7 Nobler MP, Higinbotham NL, Phillips RF. The cure of aneurysmal bone cyst. Irradiation superior to surgery in an analysis of 33 cases. Radiology 1968:90:1185-92.

8 Vergel De Dios AM, Bond JR, Shives TC, et al. Aneurysmal bone cyst. A clinicopathologic study of 238 cases. Cancer 1992;69:2921-31.

9 Martinez V, Sissons HA. Aneurysmal bone cyst. A review of 123 cases including primary lesions and those secondary to other bone pathology. Cancer 1988;61:2291-304. 
10 Jaffe $\mathrm{HL}$, Lichtenstein L. Solitary unicameral bone cyst with emphasis on the roentgen picture, the pathologic appearance and the pathogenesis. Arch Surg 1942:44:1004-25.

11 Turker RJ, Mardjetko S, Lubicky J. Aneurysmal bone cysts of the spine: excision and stabilization. J Pediatr Orthop 1998;18:209-13.

12 Hay MC, Paterson D, Taylor TK. Aneurysmal bone cysts of the spine. J Bone Joint Surg $\operatorname{Br} 1978 ; 60: 406-11$.

13 Boriani S, De lure F, Campanacci L, et al. Aneurysmal bone cyst of the mobile spine: report on 41 cases. Spine (Phila Pa 1976) 2001;26:27-35.

14 De Kleuver M, van der Heul RO, Veraart BE. Aneurysmal bone cyst of the spine: 31 cases and the importance of the surgical approach. J Pediatr Orthop $B$ 1998;7:286-92.

15 Subramaniam CSV, Mathias PF. Aneurysmal bone cyst. J Bone Joint Surg Br 1962:44B:93-101.
16 Kamikonya N, Hishikawa Y, Kurisu K, et al. Aneurysmal bone cyst treated by high-energy, low-dose radiation therapy: a case report. Radiat Med 1991;9:54-6.

17 Frassica FJ, Frassica DA, Wold LE, et al. Postradiation sarcoma of bone. Orthopedics 1993;16:105-6, 109.

18 DeRosa GP, Graziano GP, Scott J. Arterial embolization of aneurysmal bone cyst of the lumbar spine. A report of two cases. J Bone Joint Surg Am 1990; 72:777-80.

19 Amendola L, Simonetti L, Simoes CE, et al. Aneurysmal bone cyst of the mobile spine: the therapeutic role of embolization. Eur Spine J 2013;22:533-41.

20 Ohashi M, Ito T, Hirano T, et al. Percutaneous intralesional injection of calcitonin and methylprednisolone for treatment of an aneurysmal bone cyst at C-2.J Neurosurg Pediatr 2008;2:365-9.

Copyright 2013 BMJ Publishing Group. All rights reserved. For permission to reuse any of this content visit http://group.bmj.com/group/rights-licensing/permissions.

BMJ Case Report Fellows may re-use this article for personal use and teaching without any further permission.

Become a Fellow of BMJ Case Reports today and you can:

- Submit as many cases as you like

- Enjoy fast sympathetic peer review and rapid publication of accepted articles

- Access all the published articles

- Re-use any of the published material for personal use and teaching without further permission

For information on Institutional Fellowships contact consortiasales@bmjgroup.com

Visit casereports.bmj.com for more articles like this and to become a Fellow 